\title{
Ann Chapman - A Stonechat Flying High
}
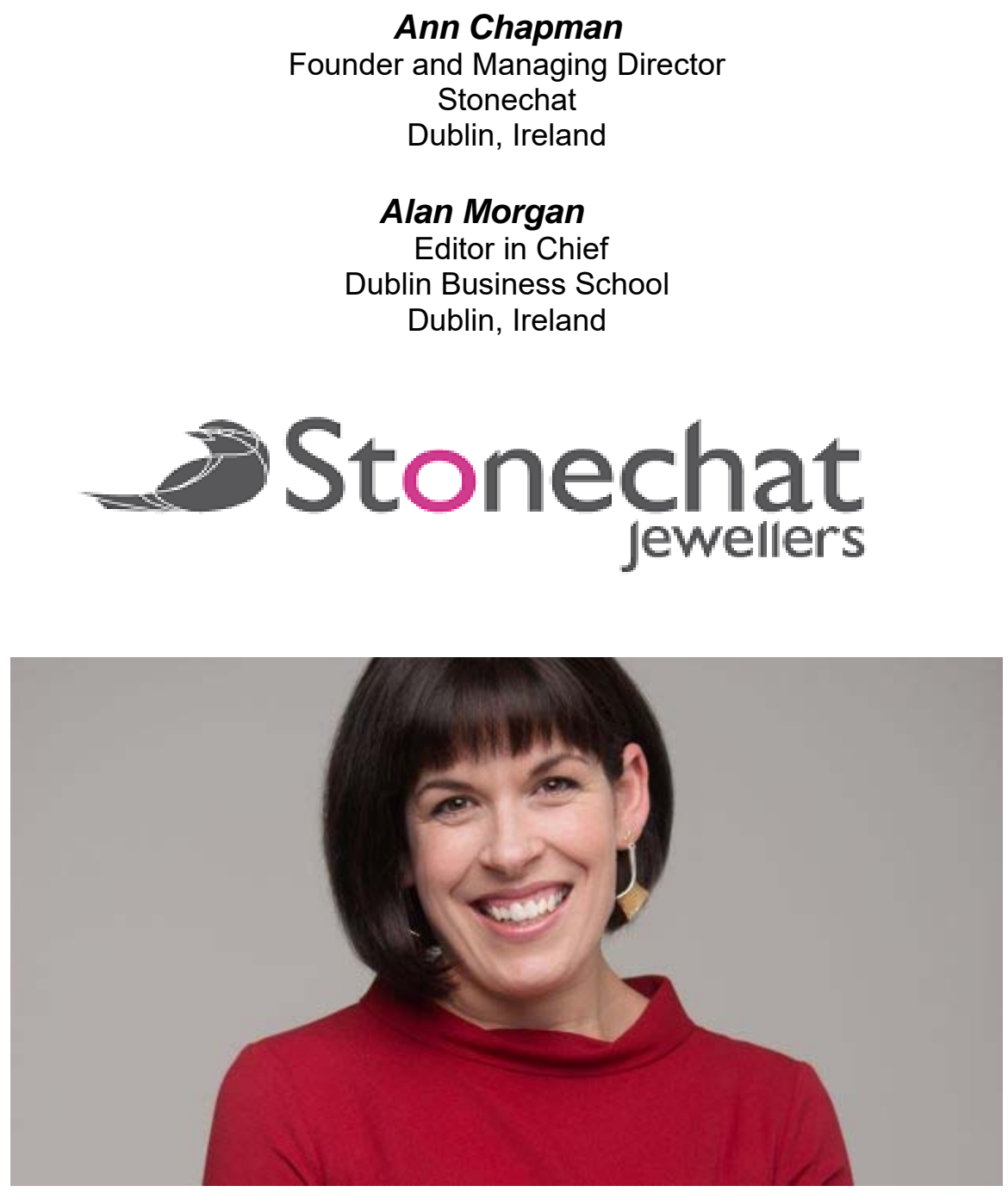

Ann Chapman: Founder and Managing Director

(C) Author(s). This work is licensed under the Creative Commons Attribution-NonCommercialShareAlike 4.0 International License. To view a copy of this license, visit https://creativecommons.org/licenses/by-nc-sa/4.0/ .

\section{Introduction}

Over the course of an academic year in 2017, once a week, I walked from our main campus on Georges Street in Dublin to one of our annexes on Balfe Street, which 
entailed taking a short cut through the Westbury Mall, just off Grafton Street. As I walked through this mall over a period of weeks, I could not help noticing this wonderfully innovative retail space, Stonechat Jewellers. As a marketing academic and a former retail buyer, I have a huge interest in innovative retailing and this store had innovation written all over It! So one of those days walking by I decided to pop in and have a browse. That was my first encounter with the marvellous Ms Ann Chapman, Founder and Managing Director of the Stonechat concept. This was also a big 'red flag' day for me, as it was the first time in a long, long time that I have been 'blown away' by excellent customer service. Of course, after my browse, I walked out with a purchase. This is what I now refer to as the 'Chapman affect', which stems from Ann's incredible charm and simplicity of communication working alongside her clever sales and marketing techniques. One cannot ignore the innovative style of her amazing jewellery designs which give the Stonechat brand a particular competitive advantage. So, after numerous more visits to her store and lots of chatting with Ann around what she was doing and where she was going, I asked her to do this interview, and Ann being the great marketer that she is, of course said yes! So, one fine October morning this year we both met for coffee in the Westbury hotel and had a chat about Stonechat.

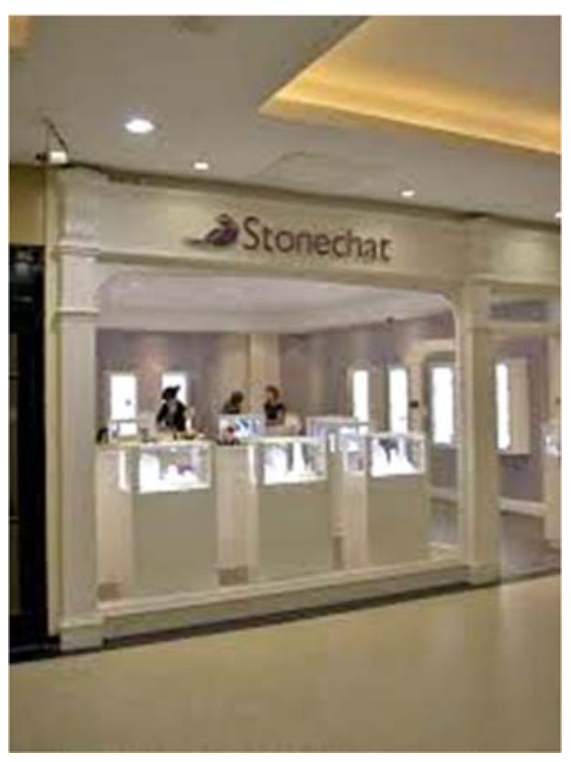




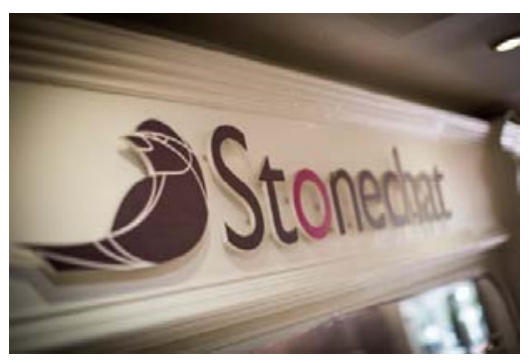

Alan: $\quad$ I would like to start off by asking a few general questions. Could you give me an introduction to your business? What's the Stonechat story? How did you get your idea and concept for the business, and why jewellery?

Ann: $\quad$ I've always been interested in working with my hands. That would be the most important thing. I was quite studious in school. My father is an academic. He's a Professor of Geology in Trinity College, and has very strong opinions on the importance of third level education. I loved the idea of pursuing a slightly alternative career but I was encouraged to get my degree first - to have in my back pocket! I decided to study European Studies in Trinity. European Studies. In different universities the programme means different things. The programmes don't always include business studies. Mine didn't! In fact, I've never studied business. Never in secondary school. Never in college. Not once! (Laughing)

Alan: WOW!

Ann: $\quad$ Yes, there you go! So, it was French, Spanish, History, and Politics for me!

Alan: I love it. Classical entrepreneurial values!

Ann: $\quad$ My degree was very enjoyable. I got to do an Erasmus year in Paris which was fantastic. But during this time, I also pursued my interest in crafts. When my degree finished, my class headed off to the Department of Foreign Affairs or off to Brussels to work with Commission etc. That simply wasn't for me.

Alan: $\quad$ So we won't expect Ambassador Chapman then!

Ann: $\quad \mathrm{NO}$ !

The day I collected the results from my degree, I literally, (this is not a lie), walked out the doors of Trinity College and walked across the road into FAS to look for a course in some kind of craft. Or hand skills or 
similar. Just something that allowed me to work with my hands. That's all I wanted.

Alan: Wow!

Ann: $\quad$ Thankfully, FAS had a course for me. I had been interested in making jewellery already and as luck would have it, they had a course in jewellery making!

Alan: $\quad$ Had you ever done anything with regard to jewellery making before?

Ann: $\quad$ No, I had messed around a bit at home, but nothing of substance. I found a short course that would bring me up to speed in NCAD. I loved that so much that I decided to go back to FAS, to-do one year course. From that, I got to go on a work placement to a jewellers in the north of Ireland called Steensons. They are a family-run jewellers in a little village called Glenarm which is on the north Antrim coast. It is the back of beyond!

Alan: $\quad$ Ok. A radical move from the comfort of Dublin?

Ann: $\quad$ Yes, but the most beautiful place on Earth. They were amazing. They are an incredible success story in jewellery and they really opened their doors to me. They gave me keys to the workshop, telling me "Work during the day and have free use of the workshop during the evenings. Come and go as you please. Work away. Whatever you need." They were absolutely fantastic.

Alan: $\quad$ So what next??

Ann: $\quad$ There was a course in Kilkenny run by the Design and Craft Council of Ireland. They take 12 people every two years so it is very, very hard to get into. I set my sights on that. It was a competitive entry process. I had do an interview and an aptitude test. Over a 100 people apply for just twelve places. The problem is that it runs every two years. If you don't get in, you have to wait two years to apply again!

Alan: $\quad$ Sounds like a big opportunity

Ann: It's a huge opportunity, some people applied as many as three times over in six 6 years!

Ann: $\quad$ At this time I was working up north in the Steenson's. There wasn't a huge amount to do in this small village anyway, so I spent my whole time 
in the workshop. I built up a portfolio and used it to apply to Kilkenny. I got in and it was amazing!

Alan: What happened next?

Ann: I was in Kilkenny for two years. It's a very intensive course where you are expected to achieve in two years what you would normally achieve in a four year apprenticeship! Hard work but I loved it.

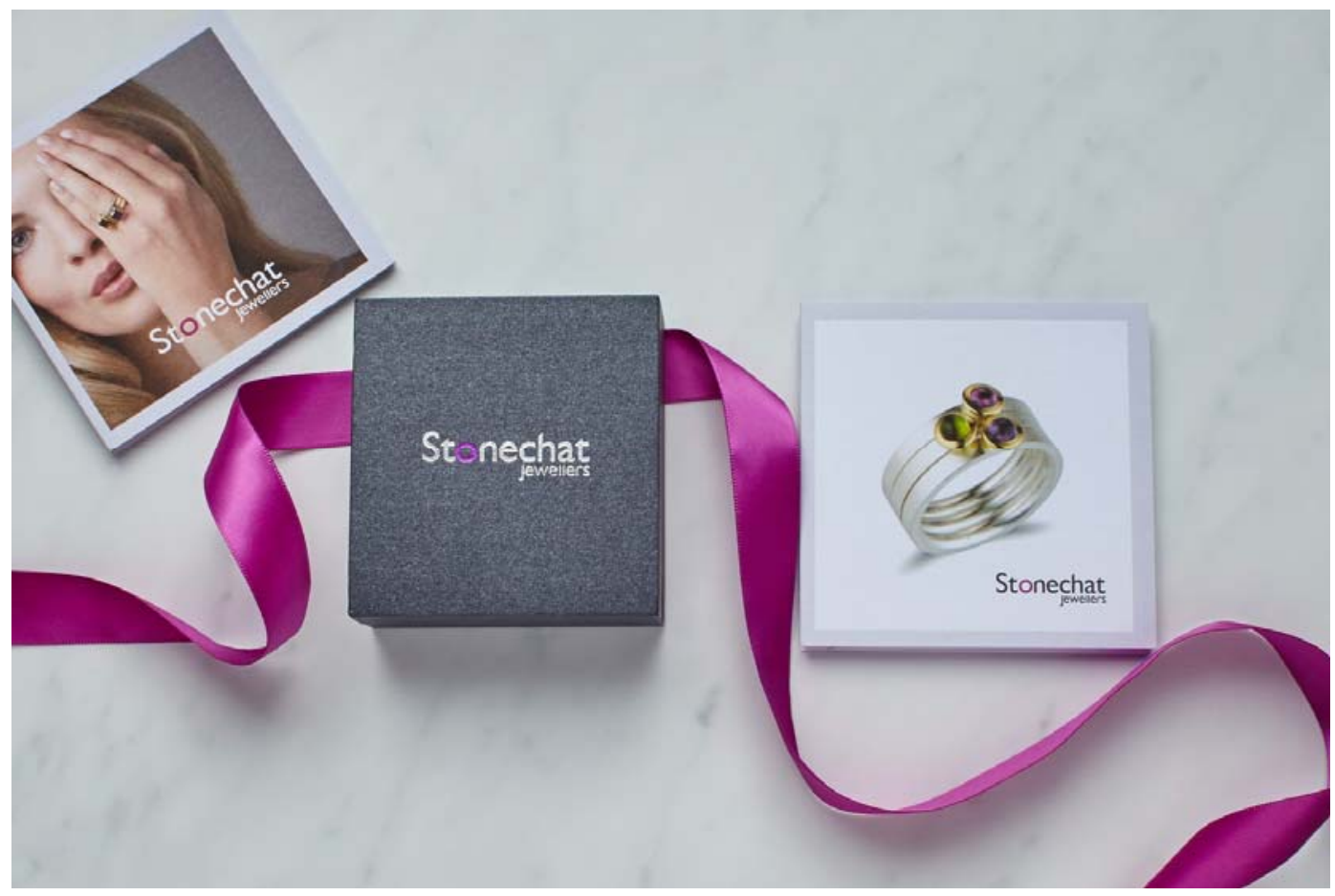

Alan: Just to digress for a minute, I am just interested in your opinion on apprenticeship education.

Ann: I'm a big believer. If you look at what is trending at the moment in education, it's the apprenticeship programmes.

Ann: $\quad$ Taking jewellery in Ireland versus jewellery in Germany as an example.There is jewellery everywhere in Germany; amazing jewellery and amazing skills. That is because they kept the original apprenticeships schemes going. There is a lesson here. They still have guilds and jewellery making is seen to be a profession. You know, you're going into a trade; learning and honing your skill on the job. Whereas in Ireland, we've lost that, unfortunately. 
Ann: I finished in Kilkenny and I didn't really know what the next step was!

Ann: I went into retail and thought that I would get a job as a sales person and do it for a few months and see how it goes.

Alan: $\quad$ And?

Ann: I worked in couple of other workshops and got some experience at the bench as well, but I loved retail, I just loved it. I Loved dealing with customers. I love being able to get it right for them. I love being able to offer amazing customer service. Customer service is so lacking Ireland, I can't understand it. That's why I'm really passionate about it, customer service is probably my biggest passion.

Alan: $\quad$ Why, why Customer service Ann?

Ann: I just love the buzz of it. The busy days and at the end of a busy day, looking back and thinking, "Yes, we did a great job today."

Ann: I ended up working for Designyard. I started as a sales assistant and then became general manager. I ran the business for five years.

Alan: $\quad$ That sounds impressive? Where were they based?

Ann: $\quad$ They were on Nassau Street.

Ann: It was a big shop, a six-story building.

Ann: $\quad$ I loved it as a business and I gave it my absolute all. But I felt that I had taken it as far as I possibly could without being given complete control of the business.

Alan: $\quad$ So, were you were frustrated?

Ann: $\quad$ Very! And at this stage it was 2007! So, recession was hitting and things were terrible. Turnover was down so I went to my then employer and said, "I think we need to make drastic changes. I think we need to have a smaller building. We need to have less staff. We need to reduce ranges " (as we had so many designers). We had a vast array of jewellery and it was too much to manage well.

Alan: $\quad$ Too much clutter. Too much retail noise???

Ann: I just knew that there was there was too much noise as you describe it. 
Ann: $\quad$ So, I proposed that we change. I said, "I think we need to look at this. We need to take our 15 top designers. We need to go to a small location. I will run it for you. I will only need one, maybe two other members of staff. We will cut our overheads dramatically and I think we will get a similar turnover". My employer said he wasn't interested. That was the catalyst. So, I did it myself!

Alan: $\quad$ So, Stonechat was born.

Ann: $\quad$ YES.

Alan: Wow

Ann: $\quad$ Yes. And everyone thought I was nuts! (Laughing)

Alan: $\quad$ So, why Stonechat?

Ann: What I had learnt managing other businesses was that Irish jewellery was so important. Designyard stocked both Irish and European pieces but this was 2007. People were now coming back to saying, "We want Irish." The handcrafted aspect was also important, having the workshop in store was key therefore. This wasn't in other stores and I saw that as a gap.

Alan: Brilliant idea. We call it The Theatre Metaphor model in Services Marketing.

Ann: $\quad$ Yes, this was great theatre! Also, being able to produce ourselves rather than always buying in gives you a lot more control and better margins.

Alan: I'm actually interested as well in your location. I think that the Westbury Mall is a really interesting location. Correct me if I'm wrong, but you kind of put it up to the other jewellers around the area? 


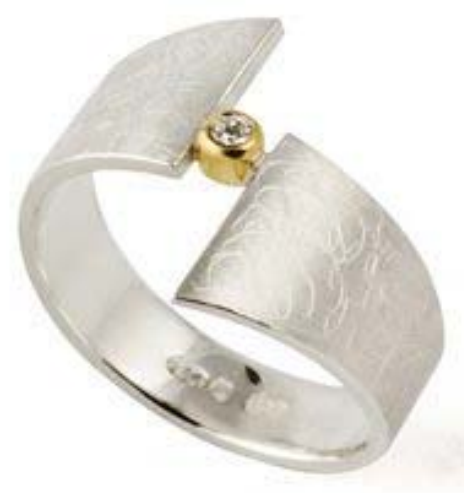

Ann: $\quad$ The Westbury Mall. It hasn't traditionally been a great location in that a lot of business come and go there.

Alan: It's quite transient.

Ann: $\quad$ Definitely. What I felt was that it's obviously prime location in that is a stone's throw from Grafton Street. But it's quite nice that you're not on a very busy street. When people are buying jewellery, it's nice to be in a more private setting. The security aspect was huge because I opened the business on my own, so I was in there on my own six days a week. There's a security guard there. There is a doorman on the hotel just outside. (Laughing). This was huge. I really wanted to have an open door, so being on the street wasn't really attractive.

Alan: $\quad$ Do you see yourself as a disruptive business in relation to not having the doorbell on the door.

Ann: $\quad$ Yes, sort of. But that was really one of the most fundamental parts of the business. Opening the door as well as showing prices! Sounds very simple eh? But not many in jewellery were doing that. Doorbells and white gloves still exist!

Alan: $\quad H o w$ did you get your idea or concept for the business and the brand, as you are a heavily branded business?

Ann: It sounds so clichéd, but when I was sitting at the kitchen table and writing a business plan. 
Alan: Really?

Ann: I went on maternity leave from the other business. I had my daughter and went back after six months...

Ann: It was 2008 , no, even later. I'd gone through the recession. I was In that other shop and I just thought that this place is going nowhere. They are not going to do what I want. I didn't know what I was going to end up doing but I knew that this was not for me anymore. I went home and I was talking to my brother, who is a savvy business person and he asked me "why wouldn't you just open your own business?" I replied, "Yes, that's great in theory. But how am I going to do that? How am I going to get the capital?" And he asked me, "Well, have you actually written a business plan?" I said, "No." And he said, "Well, go and write a business plan and bring it back and show me." So, I went home and 24 hours later, I had it finished and in front of him!

Alan: Why am I not surprised? The Ann Chapman way. Just get it done... (Laughing)

Ann It was really interesting just writing the business plan. I'm a big believer in business plans now. A big, big believer...! (Laugh's)

Ann: $\quad$ The business plan focused on things like what are the key concepts? What is important to us? Core values? What is just noise? What's the vision? All of that.

Alan: $\quad$ But what are your core values?

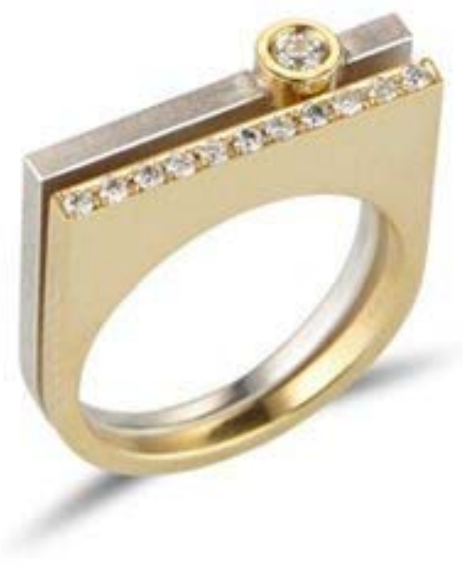


Ann: I am a big, big believer in customer service, attention to detail, friendliness. We have a lot of buzz words. Compassion would be a huge one.

Alan: $\quad$ Would they be pillars of your brand now?

Ann: $\quad$ Yes. $100 \%$.

Ann: I'm a problem solver. I look at things and see how to improve them. I look at something and say, "Do you know what - it would be so much better if they just changed this or that..!

Alan: Brilliant.

Ann: I walked out of the job. I flew to London and I walked the streets looking for amazing jewellery shops.

Alan: $\quad$ So you did you market research.

Ann: $\quad$ Yes, I did. And the funny thing I took away from it that was that there were no "really amazing" shops over there, which I felt was incredible.

Alan: $\quad$ You have a great brand and I think you have a great brand story, right? And branding is all about storytelling?

Ann: $\quad$ Yes of course it is.

Alan: $\quad$ So, did you have a brand strategy from the start or was it the Ann Chapman way?

Ann: $\quad$ Good question. I had a clear idea of what I wanted in terms of very a clean, very paired back brand with the focus on the jewellery. That was my main mantra in designing the shop, the ads, the brochures etc. It had to be about the jewellery. It was a question of taking out all of the background stuff, the noise! We have a visual product. Just show that visual product. It will sell itself.

Ann: $\quad$ That was it really. The brand was the key element. I got a graphic designer to design the logo and then we had a lovely story behind the logo. The Story behind the logo is that we are Stonechat Jewellers and a Stonechat is an Irish bird.

Alan: $\quad$ Can I ask you Ann. Is Stonechat Ann Chapman or is Ann Chapman Stonechat? 
Ann: $\quad$ Oh God. That's really tough. I would say I am definitely the main driver of the business but my team are really integral. I do the marketing. I do the radio. I work with PR. I do all of the bigger picture stuff re where are we going to be this time next year? Et cetera. The essence of Stonechat is customer service, and that's more of the team than me. I feel like I could walk away for three months and Stonechat wouldn't be affected.

Alan: You're clearly an entrepreneur. Do have entrepreneurial traits? What personality traits do you think have helped you the most in your successes as an entrepreneur?

Ann: I would say attention to detail and hard work. They are the two things.

Alan: $\quad$ Simple as that?

Ann: $\quad$ Yes! Simple as that!

Ann: I just don't believe there is anything you can't achieve if you get up early enough in the morning to do it and if you put the work in.

Alan: $\quad$ What's unique about your business model? What can you say gives you your unique selling point?

Ann: $\quad$ The workshop in store is probably the most important aspect. It gives the ability to offer bespoke and remodelled jewellery. This is a big business opportunity. Apart from that, I would say that within Ireland, we are unique with our branding approach.

Alan: $\quad$ Can you explain this more?

Ann: $\quad$ We are small and approachable. We have a clean look which customers really like. Our ads stand out as we keep them so paired back.

Alan: $\quad$ In marketing we talk a lot about brand personality. It's a huge part of how you sell your business. What do you think is your brand image in the market as brand image is what the consumer sees?

Ann: $\quad$ Tough question.

Alan: $\quad$ So, what do you think the consumer sees?

Ann: $\quad$ So this is an interesting one. I think the consumer sees our main core values coming from our quality products, they see that we are driven by 
great customer service together with our attention to detail. And also that we are accessible.

Ann: I have always concentrated on the look of an ad, making the look very clean and tying it in with our brand so that we stand out in the newspaper. There is all this noise. You have all these ads with so much text. I've always tried to pair it back, pair it back, and pair it back so that when you open the page, it's actually the white space that's nearly catching your eye because everybody is trying to fill the page that they're paying for with as much as they can.

Alan: $\quad$ Less is more?

Ann: Less is more, exactly. But actually, this is the really interesting thing. You'll love this. We've been open six years and we've advertised in the Irish Times since day one. We've done full pages and we've done half pages. We've done front pages. We've done a whole lot. And we get a huge return from it. But last Christmas, I decided to try something new. I decided to put prices in the ad. So, instead of doing one big image or four slightly smaller images, I did nine products and I put a description and a price under each one. The response to that ad was incredible. What people were saying was, "I always assumed I couldn't afford your jewellery."

Alan: $\quad$ Wow. Wow. That's incredible!

Ann: $\quad$ Before I heard the response to that ad I always thought that if somebody saw something in an ad and they liked it, they would at least go to the website to find out how much it was before deciding it wasn't for me, but actually, they weren't!

Alan: It kind of gives me great hope because I'm a marketing traditionalist in many ways and it still goes back to the four P's of marketing, 'Price, product, promotion, and place'.

Ann: $\quad$ Exactly. Give the customer all of the information. Do not make them work to find out and don't assume anything.

Alan: $\quad$ You mentioned online there. How do you compete against online, or do you see online as competition?

Ann: We work really hard online. It doesn't bring great revenue. I would love it if our online business was stronger. It's something we're definitely looking at. It's a very tricky thing because we are so customer service 
focused and our product is so different. What makes us so unique, means that we will not always succeed online. Our website really works as a catalogue rather than as a sales channel.

Alan: $\quad$ Would you buy a piece of jewellery worth a 1,000 euro online?

Ann: No. I don't think l'd buy anything worth a 1,000 euros online to be honest but I'm probably quite traditional in that respect.

Alan: No, you're not. This is a common answer!

Ann: $\quad$ People may buy more as we move forward with the business. But I am not sure.

Do we compete with online or do we keep progressing our customer service, the customer experience, all of that. These areas are our main competitive advantages.

Alan: $\quad Y o u$ mentioned before that you're part of the Women Entrepreneurs' group?

Ann: $\quad$ Yes. Going for Growth. It's an amazing group. I've never sat around a table with such a group of successful businesswomen before. I was the smallest fish in that pond. They are all incredible. Every person has a very different business but all had similar stories. I learned that everyone faces the same challenges, whether you're in healthcare, fashion, IT, whatever it is. We all face the same challenges. It's a great network. What I also took from that meeting is that I think a lot of people in business suffer from imposter syndrome.

Alan: $\quad$ Maybe just explain that.

Ann: It's where you always feel that you're kind of winging it. You second guess yourself. Have I created this? You don't believe in yourself or in what you've achieved. I would say that the Going for Growth program makes you take stock of what you've done and realize that you can actually do so much more.

Alan: It sounds great.

Ann: $\quad$ Yes, it is just great.

Alan: $\quad$ Based on your entrepreneurial mind-set, is there any specific education path you would recommend to follow to become an entrepreneur? 
Ann: $\quad$ Well I'm not sure because I didn't do any of it, (I've never gone to one business class, lecture etc.) which I know is not a great story for you.

Alan: It's a brilliant story, brilliant story.

Ann: $\quad$ I wonder had I done business in school and in college...

Alan: $\quad$ Where would you be now?

Ann: $\quad$ Where would I be now?

Alan: $\quad$ You started this business six years ago and you mentioned you were on your own, it was you in your own in the store. Is that a lonely place?

Ann: $\quad$ Absolutely! (Laughing)

Alan: $\quad$ So, tell me about your best and your worst days.

Ann: $\quad$ The fifth birthday was a great day. We had grown from, starting on my own to a team of five within five years which was great. The whole team were on board and it was a big celebration.

Ann: $\quad$ The worst day was, undoubtedly, about three days into opening. I opened on a Saturday morning and then from that day to Friday of the next week, not one customer called in. There was literally nothing. People weren't even walking in the door. They were just walking by. And I just sat there. I went home to my husband and I cried and I said, "What have I done? This is a disaster." I couldn't believe it. But he said, "Don't be ridiculous. You're three days in. What did you expect?"

Ann: $\quad$ And sure enough, we got some PR and suddenly, we've got people coming. And then it just started to happen. I would say since that low point at three days old. It's gone up ever since.

Alan: $\quad$ Do you think it's important to remember the worst days?

Ann: I would tend to look more towards the positive than the negative. I often say to the girls in the shop when we're working on procedures, that in the starting days, l'd be handing you a scrap of paper that said 'Do this today' and now it's much better. We have an extensive excel calendar for the workshop and we are process driven, much better! 


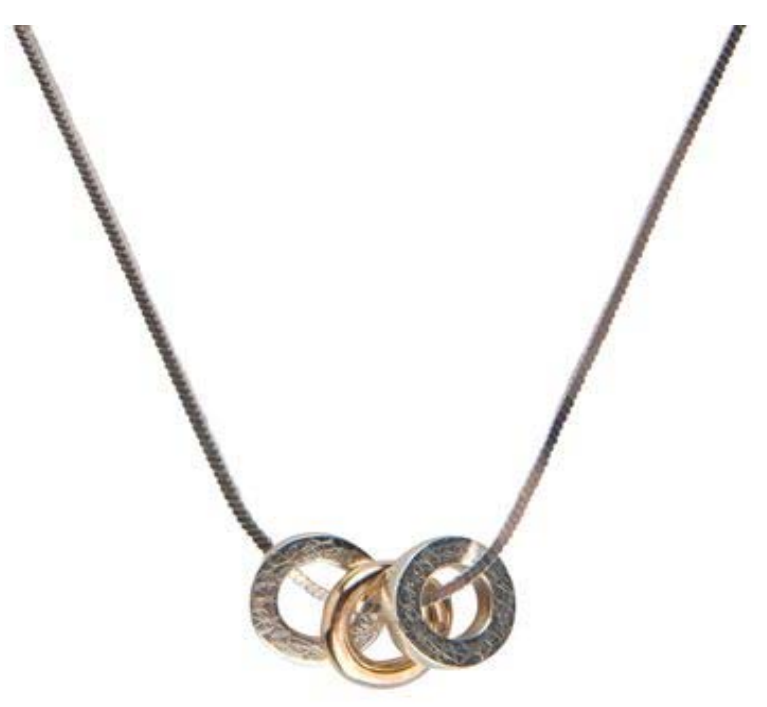

Alan: Is there any specific piece of advice you would give to an entrepreneur starting out or a graduate or somebody who has a business idea and who is not sure and has that classic fear factor that you speak about, what would you say to them?

Ann: I would say just go for it. I think definitely take the risk and go for it but at the same time, I would write that business plan. I would do a P\&L. If you don't have a mind for figures, get somebody to sit down and write it with you. Make sure that you know that you can succeed. That there is potential. Do your cash flows and sales projections, all of that stuff because it is important for the business to succeed. Break it down. I had a sales target for every single day from day one. I knew that if I made $x$ amount every day, I was winning. As my overheads changed, I changed that.

Ann: $\quad$ Everyday going home, I used to ring my mum, and she'd say, "Did you achieve it today?" And l'd tell her, "Yes." Or "No" or whatever.... "Or I did double yesterday" I was always in control of the figures. I still am. I watch them religiously.

Alan: $\quad$ You set targets in your business but what do you think about targeting yourself as an entrepreneur? 
Ann: $\quad$ Yes, very important and that's something that the "Going for Growth Group" would encourage greatly. It's something that I think you lose as your business gets busier and you're in the moment. You're firefighting and it's all going great but you really have to always be forcing yourself to take that step back and say, "Okay, it's going great now but is it going to be going great in two years' time if I'm not making these decisions?

Alan: $\quad$ A couple final questions, based on that last question about targeting yourself and driving yourself and all that, what's the road ahead of Ann Chapman's Stonechat, Stonechat Ann Chapman?

Ann: It's a very good question. Definitely expansion.

Alan: $\quad$ Do you think the brand has travel ability?

Ann: $\quad$ That comes back to the question. Is Stonechat Ann Chapman? I feel that we would have to tailor it maybe? Not sure?? But it would be about pushing more of our products, our collections. But expansion is definitely down the road. I want to expand, otherwise I'd be bored. (Laughing) I don't sit still!

Alan: $\quad$ The Classic entrepreneur (laughs)

Ann: $\quad$ Yes. My brain is always thinking of the next thing.

Alan: Final question. It's a loaded question, taken from a famous entrepreneurial book. You have two teleportation devices? Where do you place them and why?

Ann: Do I get a bit of time to think about that one?

Alan: If you could teleport yourself to somewhere immediately for a day or a few days, where would you go and why would you go there? Because it says something about the person and the entrepreneur. You can take this from a personal perspective or a Stonechat perspective? It's a classic question that entrepreneurs are always asked

Ann: $\quad$ Oh wow.......Really? Ok.

Ann: I think I prefer to focus on where I am rather than dreaming about where I could be! I don't think I'd go anywhere to be honest... I'm very happy where I am! 


\section{Conclusion}

As we departed the Westbury, going our separate ways, I watched Ann walking back towards her store and observing her stature, posture and walking style it is clear that she is the embodiment of her business as she demonstrates both a cool confidence and a powerful demeanour. I could not help thinking that I had not just interviewed Ann Chapman, but a disruptive entrepreneurial star in the making.

Stonechat and Ann Chapman are an incredible story.Earlier this year, Stonechat jewellers scooped the coveted prize of 'Jewellery Store of the Year' at the Retail Excellence Ireland awards. Ann Chapman has been shortlisted for The IMAGE Businesswoman of the Year Awards 2018 in the category, Creative Business Women of the Year. We will watch this space with interest..! 